RGSA - Revista de Gestão Social e Ambiental

Maio - Ago. 2010, v.4, n.2, p. 156-168 ${ }^{1}$

www.gestaosocioambiental.net

\title{
BUSINESS ETHICS IN A LEASING PRODUCT OF A FINANCIAL INSTITUTION: A CASE STUDY IN AN AFRICAN COUNTRY
}

\section{Roberto Patrus-Pena}

Doutor do Programa de Pós-Graduação em Administração da Pontifícia Universidade Católica de Minas Gerais. robertopatrus@terra.com.br

\section{Claudia Marques}

Especialista do Do it consultoria (Moçambique. cmarques@doit.co.mz

\section{Patricia Bettencourt}

Especialista. Universidade Apolitécnica (Moçambique). pbettencourt@doit.co.mz

\begin{abstract}
Is it possible that a commercial bank offers a product that is simultaneously ethical, economically viable, socially fair and environmentally correct? This is the question that guided the elaboration of this paper. The object of this study is a product that results from a partnership between Millenium bim, a Mozambican commercial bank, and the Maputo Taxi Drivers Association. It made possible the offer of a leasing product in order to buy more recent vehicles with special conditions to the taxi drivers, in a city where the fleet of taxis is old, uncared and not reliable. The theoretical referential describes Lozano's Business Ethics model (1999), through the organisation proposed by Patrus-Pena (2004). It suggests to integrating ethical considerations more effectively into core business operations and strategy. It is a case study whose data was collected through semi structured interviews. The data analysis revealed the practical realization from the integration viability between a company's economic advantages and the community's social development, as suggested by Porter and Kramer (2006) and Burke and Logsdon (1996).
\end{abstract}

Keywords: Business Ethics, Sustainability, Corporate Social Responsibility, Africa.

\section{ÉTICA EMPRESARIAL EM UM PRODUTO DE LEASING DE UMA INSTITUIÇÃO FINANCEIRA: UM ESTUDO DE CASO EM UM PAÍS DA ÁFRICA}

\begin{abstract}
Resumo
É possível que um banco comercial ofereça um produto que seja simultaneamente ético, economicamente viável, socialmente justo e ambientalmente correto? Esta é a pergunta que guiou a elaboração deste artigo. O seu objeto de estudo é um produto que resulta de uma parceria entre o Millennium Bim, um banco comercial de Moçambique, e a Associação dos Taxistas de Maputo. Trata-se da oferta de um produto de leasing com o propósito de comparar carros mais novos em condições especiais para os taxistas, em uma cidade cuja frota de taxis é velha, sem manutenção e não confiável. O referencial teórico descreve o modelo de

\footnotetext{
${ }^{1}$ Recebido em 03.03.2010. Aprovado em 17.07.2010. Disponibilizado em 31.08.2010. Avaliado pelo sistema double blind review
} 
Business Ethics de Lozano (1999), a partir da organização proposta por Patrus-Pena (2004), que propõe integrar considerações éticas às operações fundamentais do negócio e à estratégia do negócio. Trata-se de um estudo de caso cujos dados foram coletados por meio de entrevistas semi-estruturadas. A análise dos dados revelou a viabilidade prática da integração entre as vantagens econômicas para a empresa e o desenvolvimento social da comunidade, como recomendam Porter and Kramer (2006) e Burke and Logsdon (1996)

Palavras-chave: Ética Empresarial, Sustentabilidade, Responsabilidade Social e Empresarial, África.

\section{1- Introduction}

What is the role of business in the reduction of poverty? How can a financial institution contribute to the development of a poor country, by means of its products and services? Is it possible that a commercial bank offers a product that is simultaneously ethical, economically viable, socially fair and environmentally correct? It is a case study undertaken at Millennium bim, a Mozambican commercial bank. The object of this study is a specific program/product denominated "More Taxi for Me". This product results from a partnership between Millenium bim and the Maputo Taxi drivers Association (Associação dos Taxeiros de Maputo - ATAXIMA), which made possible to offer a leasing product for the acquisition off more recent vehicles with special conditions to the taxi drivers.

In Maputo, capital of Mozambique, the fleet of taxis was (and still is) old and uncared. The cars were not reliable. There was not a single brand new taxi, zero km, at the streets of the capital. None of them had any advertising (who was up to advertise his brand in an old and ugly car?). The "More Taxi For Me" (Mais Taxi Pra mim) Program is part of the marketing strategy of the company which uses the expression "pra mim" (for me) when communicating with the public. When it concerns property credit, it is said "a new house for me” and regarding the women's credit card they say "a card just for me”. The same goes for the social responsibility program "Mais Moçambique pra mim” (More Mozambique for Me), resultant of a partnership between Millenium bim and the Fundação Lurdes Mutola (Lurdes Mutola Foundation) aiming to promote actions to support Education and Infantile and Juvenile Sport.

The theoretic referential of this paper is based on the premise that the triple bottom line of business sustainability must be incorporated in the business itself. According to Porter and Kramer (2006), many firms' corporate social responsibility (CSR) efforts pit business against society, when the two are actually interdependent. Successful corporations need a healthy society. At the same time, a healthy society needs successful companies. The essential test that should guide CSR is not whether a cause is worthy but whether it presents an opportunity to create shared value - that is, a meaningful benefit for society that is also valuable to the business (Porter \& Kramer, 2006). An integrated sustainability perspective is supported on a Business Ethics model which comprehends the ethics of conviction (based on deontological principles), the ethics of responsibility (based on the consequences of actions) and the ethics of virtue (the virtue as a value turned into an usual daily act), according to the proposition of Lozano (1999) and Patrus-Pena (2004).

The article is organized into five parts, being this introduction the first one. The second part describes the Business Ethics Lozano's model (1999) arisen from the organization carried out by Patrus-Pena (2004). The third part describes the research methodology, namely an exploring case study which data was collected through semi structured interviews. The fourth part concerns the working out and elaboration of the "More Taxi For Me" program, a product offered by the Millenium bim, and taken as an outstanding example of an economically viable product which can contribute to the social development of an African country. The fifth part regards the conclusions and the limits of the study as well as the 
recommendations for the improvement of the program carried out by the financial institution. Among the conclusions it can be highlighted the feasibility integration between the profits of a company and the social development of the community, by means of a product which gathers social qualities. As Porter and Kramer (2006) pointed out, a new approach is needed to integrating social considerations more effectively into core business operations and strategy. It can as well be concluded that a glance at the business sustainability, points out possibilities of the Taxi Leasing improvement, namely as to its environmental dimension.

\section{2-The theoretical referential}

The research described in this article is based on a Business Ethics (BE) model, which aims to integrate ethical values and responsibility of corporate behaviour simultaneously, and the application of these values in the organisational culture. The BE theoretical mark proposed by Lozano (1999) and further studied by Patrus-Pena (2004) has its focus in the business and must be observed in the management practices. It involves the perspective of the Ethics of Conviction, the perspective of the Ethics of Responsibility and the perspective of the Ethics of Virtues.

Figure 1 graphically represents the model's components. Each one of its single dimensions is presented separately, due to didactical reasons. The intersection among the three spheres represent the core of Business Ethics.

Figure 1: Graphic representation of BE Model

\begin{tabular}{|l|l|}
\hline Referential BE Model & $\begin{array}{l}\text { Graphic } \\
\text { Representation }\end{array}$ \\
\hline
\end{tabular}

(a) Ethics of Conviction

(b) Ethics of Responsibility

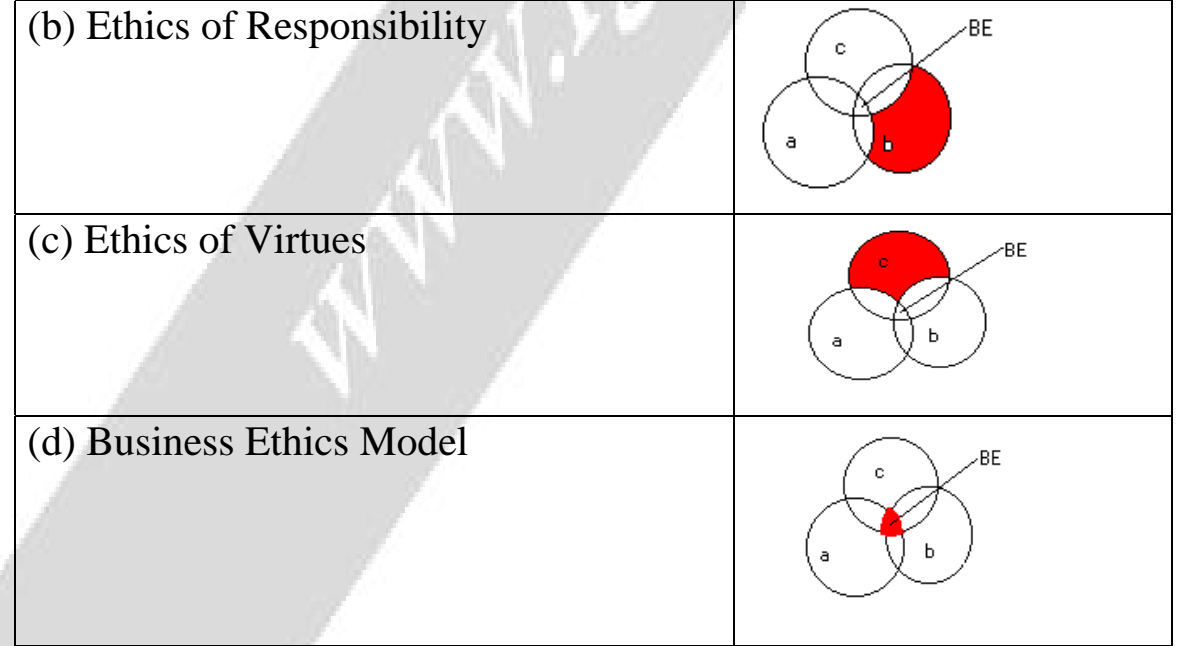

Source: Patrus-Pena (2004).

Every business aims at profits. But not all business aim at profits at any cost. The ethical company sets up limits of its economic return, defined by the ethics of conviction which guides the company's decision process. Usually, the humanity's values are stated in an ethics code or in a company's values declaration (Singh \& Lefebvre, 1992; Benson, 1989; Andersen, 1984; Cressey \& Moore, 1983; White \& Montgomery, 1980; Rainborn \& Paine, 1990; Andersen, 1992; Brooks, 1989; Stevens, 1994).

The simple establishment of values for the organization doesn't mean necessarily that the company is ethical. Such codes can work as control instruments, instead of establishing 
the ethics of conviction (Francés, Borrego \& Velayos, 2003). It can also be a simple legalistic tool. The statement of an ethics of conviction is a necessary dimension, but not sufficient for the definition of the referential ethical BE mark (Lozano, 1999).

Which values guide the search of economic profits that any company aims at? The answer to this question establishes the main values, of deontological meaning, which compels the company to act ethically. The humanity ethics should be stated before the strategic planning because it defines the means to accomplish the corporate purposes. According to Kant's ethics, categorical imperative is understood as the moral obligation which becomes compulsory as a duty by means of expressing the necessity and universality. That is the determination of will by reason and the effectiveness of the imperative to everyone (Kant, 2002). Categorical imperatives are practical laws that are unconditionally valid regardless the effects that may outcome (Kant, 2002). Unlike the hypothetical imperative, by which necessity is limited by the will of achieving an effect ("if you want...you must..."), the categorical imperative is a necessity of reason ("you have to because you must" or "you must and that is that") (Kant, 2002). According to MacIntyre (1998), the categorical imperative is not bound under any condition. It just has the pattern "You must do it accordingly" (...) Why? There is no reason. You just have to do it" (Macintyre, 1998, p. 188-189).

By the ethics of conviction the behaviour has to be guided by categorical imperatives which determine the action, without taking into account its results. That aprioristic concept, when exclusive, seems not to be much suited to business which, by definition, aims at profits. In the business world it would be hazardous not to regard the profits of a corporate behaviour. Security and environment are values declared by big international companies as categorical imperatives (Patrus-Pena et al, 2004; Patrus-Pena et al, 2007). Although they try to impose these in the organisational process as categorical imperatives, the values of health and security find consequent justifications to be followed. The infringement of them brings along material and intangible damages.

At present, the effects of some actions may cause permanent damages to the people, the environment and the mankind. The ethics of responsibility takes into consideration the dimension of the responsibility toward the future. According to Weber (1959), the ethics of responsibility stands on the concept that we must to be responsible by the predictable consequences of our actions. The principle of responsibility is presented by Jonas (1995), who mentions the power of science as a consequence of the strength power of technology. We consider that his thesis may be perfectly applied to the power of companies which, lately, produce or use technologies. We may add that the concept of sustainability, which claims for the care with future generations, changes the exclusively economic goal of a company. It changes the short term to a long term perspective, and adds to the economic goals the social and environmental ones (Elkington, 2001; Nosso Futuro Comum, 1991; Almeida, 2002; Coral, Rossetto \& Selig, 2002; Atkinson, 2000; Hoffman, 2000; Gladwin, 1995; Daly \& Cobb, 1994; Jennings \& Zandbergen, 1995; Shrivastava, 1995a; 1995b).

The concept of sustainability reinforces the dimension of future and responsibility that Jonas (1995) claims. Though, according to Lozano (1999), the analysis of stakeholders is a privileged mean to work up the integration between power and responsibility (Lozano, 1999:122). We consider that the concept of sustainability must be present in this conciliation since it includes the dimension of future. Future generations are not stakeholders that companies deal with. Likewise, environment is not a stakeholder; In fact, it should not be named stakeholder, except in a symbolic and amplified meaning. According to Carroll (1989), stakeholders are groups or individuals with whom the organisation interacts or maintains interdependence, as well as every individual or group that can be affected by the actions, decisions, policies, practices and objectives of the organization (Carroll, 1989, p. 60). So, the interaction between power and responsibility demands an amplification of the concept of 
stakeholder which allows us to insert the dimension of future that tends to vanish if we only focus on stakeholders that companies deal with (Clarkson, 1994; 1995; Freeman, 1984; 1994).

The ethics of responsibility, second vertex of BE, would be considered by Kant as an hypothetic imperative, due to the dimension of future claimed by Jonas (1995) that aims to accomplish long term targets, which would be for Kant an heteronymous ethics, of material contents. However, we consider that the company should mind the external environment and future scenarios, but that does not mean it should not state the duty to respect the bare minimum ethics hereby represented by the ethics of conviction, first vertex of BE.

Kant's thoughts may be the structure for the instrumental use of ethics under economic purposes, which would configure an hypothetical imperative bound by environment, therefore heteronymous. Likewise, if we turn to ethics for economic, social and environmental purposes within a sustainable perspective, in a long term, we also configure the heteronymous character (not rational) as it introduces material purposes (not formal). Then, what is the contribution of Kant to set an ethics formulation within the companies? Since we are joining apparently opposite ethics dimensions, we work with the idea of highlighting some coordinates and not to use a closed synthesis. As it seems to us ingenuous to depreciate corporate action effects, in a world marked by uncertainty and by the threat to its survival, we cannot dispense a minimum of rationally based moral. According to this perspective, we consider that Kant offers us the demand of a moral act that must have something universal (suitable to everyone) and required by reason. According to Kantian focus, without this demand corporate action would only have a profitable qualification, and not a moral qualification.

However, how do we know if values declared by the company are in fact present in its relationship with stakeholders and environment, in the search of its profits? The answer to this question is the heart of the ethics of virtues called by Lozano (1999) as generating ethics of conventional moral, third vertex of $\mathrm{BE}$, considered in sequence.

The generating of virtue, called by Arruda, Whitaker and Ramos (2001) the value that becomes a habit, means to certify that the proclaimed values by the company are rooted effectively in the practices and administrative processes. The managerial ethics demands that the organisational culture expresses the values assumed and affirmed by the company. Virtue is here understood as the value converted into act (Solomon, 1993). The value is updated by the person's usual behaviour. Only the repetition of behaviours and procedures by the influent majority of a group can generate tradition, an essential element of the organisational culture (Schein, 1968). Behaviours of different persons of a group, when becomes usual, create habits of that group. On their turn, these habits influence the behaviour of the persons, establishing the dialectic of the relationship between ethos as a habit and ethos as a tradition, so well described by the phenomenology of the ethos of Vaz (1988).

This triple ethical reference proposed by Lozano (1999) and developed by Patrus-Pena (2004) - conviction, resonsability and virtue - tries to verify the congruence between the three aspects of business ethics: a) ethics of responsibility - concerned with the consequences of the conducts and its impacts even during long periods; b) ethics of conviction - concerned in being faithful to the values and ethical criteria that orientate the conduct; c) ethics of virtues that reflects behaviour of individuals in the managerial context.

The intersection among the three ethical approaches, illustrated in Figure 1, points out to the need to consider ethics applied to business and managerial activities. Therefore, its focus is the organisation (Lozano, 1999; Patrus-Pena, 2002; 2003; Pires, 2003; Dal Mas, Patrus-Pena \& Teixeira, 2009; Dal Mas \& Patrus-Pena, 2008). That approach refuses the business ethics compensatory dimension, so present in the sustainability theme, through which the company would try to make up the impacts of its management action by means of social and environmental programmes detached from its core business. According to Porter and Kramer (2006), many opportunities to pioneer innovations to benefit both society and a company's 
own competitiveness can arise in the product offering and the value chain. For them, integrating business and social needs takes more than good intentions and strong leadership it requires adjustments in organization, reporting relationships, and incentives. Few companies have engaged operating management in processes that identify and prioritize social issues based on their salience to business operations and their importance to the company's competitive context (Porter \& Kramer, 2006).

The presented Business Ethics approach requires that the triple bottom line shall be integrated in a single bottom, including simultaneously the economic, social and environmental dimensions, as figure 2 illustrates.

The integrated perspective of sustainability finds support on the business ethics model which integrates the ethics of conviction (based on deontological principles), the ethics of responsibility (based on the actions consequences), and the ethics of virtues (virtue understood as the value converted into daily and usual act). The company's actions, including products and services, relationships and decision making processes ,should be the synthesis of humanity and responsibility values towards the stakeholders that the company interacts with.

Figure 2: Compensatory Sustainability X Integrated Sustainability

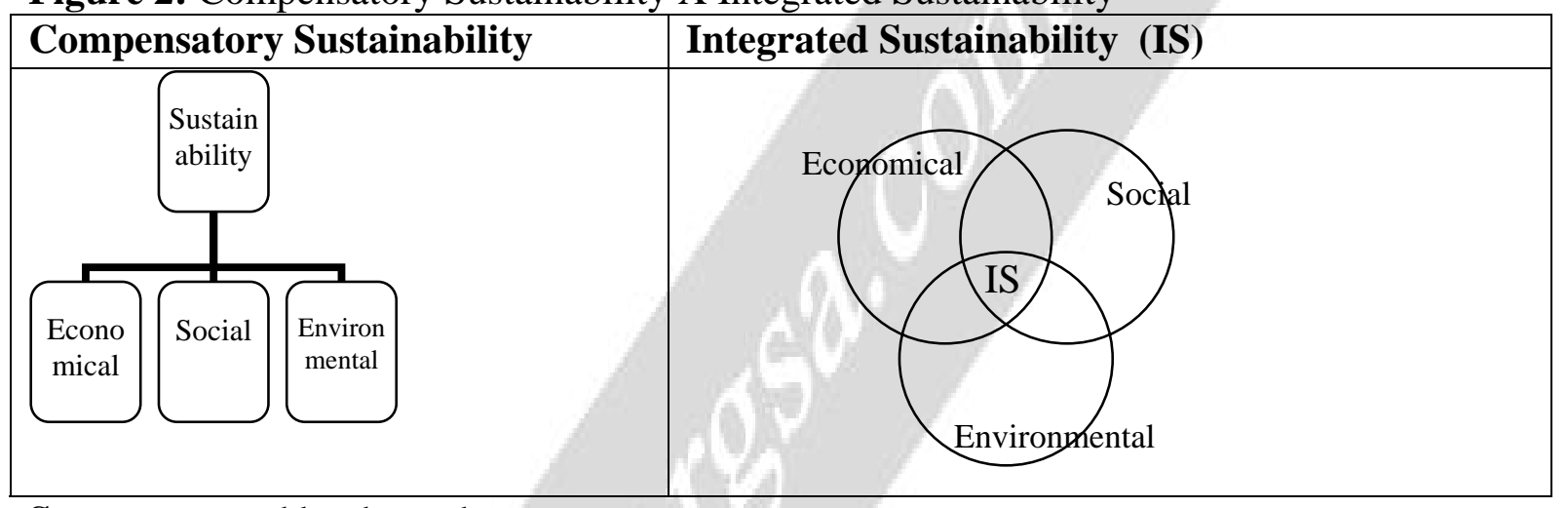

Source: created by the authors

That synthesis reflects the tension between opposites and the search for the solutions in order to overcame the differences and to integrate the ethical principles and the sustainability tripod in daily business action. According to Burke and Logsdom (1996), the failure to find strong empirical support for the relationship between socially responsible behaviour and financial performance has been troubling. Without a clearcut understanding of strategic benefits that may accrue to the organization, it is more likely that top management will not invest in CSR practices which contribute to the long-term success of the firm. "How to reorient CSR toward a more strategic perspective is the key to inspiring more CSR activities, thus serving stakeholder and societal interests more fully” (Burke \& Logsdom, 1996:495).

According to Porter and Kramer (2006), the prevailing approaches to CSR are so fragmented and so disconnected from business and strategy as to obscure many of the greatest opportunities for companies to benefit society. Leaders in both business and civil society have focused too much on the friction between them and not enough on the points of intersection. The mutual dependence of corporations and society implies that both business decisions and social policies must follow the principle of shared value. That is, choices must benefit both sides. According to the authors, if corporations were to analyze their prospects for social responsibility using the same frameworks that guide their core business choices, they would discover that CSR can be much more than a cost, a constraint, or a charitable deed-it can be a source of opportunity, innovation, and competitive advantage. When looked at strategically, corporate social responsibility can become a source of tremendous social progress, as the 
business applies its considerable resources, expertise, and insights to activities that benefit society (Porter \& Kramer, 2006). The case study presented hereby demonstrates, we hope so, it is possible that a firm jointly serves its own business interests and the societal interests of one of its stakeholders.

\section{3- Methodological procedures}

The hereby-described research is a case study, performed at the Banco Millenium bim, a financial institution from Mozambique, East African, ex-colony of Portugal. Millenium bim is a signatory of the Global Compact, a United Nations initiative for companies regarding ten principles about Human Rights, Environment, Working Relationships and Fight Against Corruption. Millenium is a Portuguese financial group and "bim" stands for its Mozambican affiliation.

Some initiatives of the Bank's Marketing Department were studied in detail, in order to analyse its products and campaigns based on the theoretical referential system. In this paper, we analiysed the product Taxi Leasing, developed in the "More Taxi For Me" campaign. In addition to learning how the product was developed, we looked for knowing the values which directed the decision process regarding its working up.

As a research tool, interviews with the Bank CEO and the Marketing Manager were undertaken, to gives us the banks perspective. The President of Maputo Taxi Drivers Association (Associação dos Taxeiros de Maputo - ATAXIMA) was also interviewed, in order to obtain data on the partnership and to compare with the company's statement. Finally, we interviewed a taxi driver not participant of the leasing, in order to know his point of view regarding the subject. The interviews, in number of four, have been half-structured.

The purpose of the research which was on the basis of the investigation was as follows: is it possible for a Bank to offer a product which is simultaneously economically viable, socially fair and environmentally correct? Is the program More Taxi for Me in compliance with the Business Ethics model, i.e., bringing together ethical values, responsibility towards the stakeholders and virtue? Is it about a sustainable product, which simultaneously associates economic, social and environmental purposes? If so, in what perspective: integrated sustainability or compensatory sustainability?

\section{4- Data analysis}

According to the Marketing Manager of the Bank, the first step for the birth of the program aimed to support the renewal of Maputo city taxi fleet was the realization of the fleet's critical condition, which is old and in bad conditions of conservation. According to ATAXIMA President's statement:

The taxi drivers were unsatisfied with the condition of the taxis; the tourists, the best clients, did not trust any car unless after previous reference of other tourists. Despite the Ministry of Tourism and the Town Hall's pressure to improve the appearance of the cars, the Association was facing problems to get the support for the car fleet's renewal.

According to the Marketing Manager of the Bank, that critical situation showed a good business opportunity. "A necessary condition to take advantage of an opportunity was portraying itself: there was the wish of the people, concerned to renew the fleet”.

The initiative for the partnership is claimed by both parts. According to the President of ATAXIMA, the Association called on the Bank, as "there was a strong pressure to improve the fleet”. The Marketing Manager stated: 
I went to the Polana Hotel taxi-rank and asked a driver if they were organized, how the legal authorizations were granted as well as the spots in the ranks, if there was any association, etc. I eared then there was an Association called ATAXIMA and I got the contact of its President.

In his interview, a taxi driver of the city, whose car is old and badly maintained, stated that the Association had not called on the Bank. Associated to the ATAXIMA, though he doesn't pay his fees, he justified his situation by stating that ATAXIMA had never cared for the taxi drivers. When he was inquired if he intended to put in for a new car, he said he was interested, but objected to the criteria of the grantees' selection and declared that the instalment's amount was too expensive for his conditions.

Established the possibility of a partnership, it was proposed for the Bank to set up the product and its parameters. From the analysis of the Marketing Manager' speech, we found out that the environment parameter was out of his speech. The economic value guided the analysis of the business feasibility, complemented by the social parameter:

Under normal circumstances none of the taxi driver clients had the profile to get credit, as they had low balances and low allowance for buying a new car. Yet, there was a group that having no high balance, were never being close to zero and had neither unpleasant incidents nor debit balances in their accounts. (...) In extenuation of the risk, the Bank would advertise on the cars, as counterpart to ease the credit. The choice of taxi leasing as a product was also a way of increasing the guarantee, as in that financing model, the object belongs to the creditor. If the taxi driver does not fulfil the conditions, the creditor can promptly regain the vehicle. The Association pledged to help the vehicle's regaining of any member who failed the obligations. The taxi drivers are also known and the cars would be painted with the advertising, making its identification easier. (Marketing Manager of the Bank)

The social dimension was also considered by the Managing Director's evaluation of the financing conditions: "the leasing obliges to a starting down-payment and this one was insufferable for the majority of the members. Once again, the social dimension was stronger: the product was created without any entrance money. The credit granting was assured, a prerogative of the honest citizen.

According to the Marketing Manager,

All those precautions were a way of minimizing the risk, but they were completely out of the banking operation's common sense approval. The cars had a strict short value. Following commercial common sense, a business should be done not in compliance of its guarantee, but in conformity to the worth of the operation, as the activity of the bank is not to take hold of the guarantees and try to sell them afterwards. The purpose is to attract resources and to grant credit.

The CEO of the Bank concluded the reasoning: 
Under the sustainability logic, the social impact of the operation becomes an element of the decision process. It is believed that the extent of sustainability is at hand exactly by the possibility of joining the social dimension together with the negotiable responsibility".

Once defined the risks, the warranties and the social impacts of the program, it was just a matter of making the partnership work and defining its expected results. The product was only offered to members of ATAXIMA, that were eligible for the leasing, according to the bank financial criteria. In order to standardise the advertising and the branding of the project, all the cars should be from the same brand. The Bank lead the negotiation process with the supplier in order to use its better dealing power to get all cars from same brand, same year of manufacture, same white colour and a better price. According to the CEO of the Bank, this bank accessibility was also different of the traditional procedures, since it is not the bank function to purchase for its clients; it was a social service aggregated to the commercial product. Another characteristic of sustainability is that economic and social purposes were acting together. Economic purposes were side-by-side with the social purposes of Millennium bim.

Ten leasing contracts were celebrated, without any initial down payment, with prices and terms current in the market. One of the demands of the bank was to request to the Taxi drivers that they must have a comprehensive car insurance, something odd among them. Taxi drivers were also demanded to present proof of third party car insurance, which they must have by law, but not made by all of them.

After a year from the first offer, other ten more operations were done with some innovations. In a second phase of the project, cars are three years more recent than those from the first operation, improving the quality of the fleet. The new vehicles also have a taximeter, which is an extraordinary evolution considering the general conditions of existent taxis in the city.

In November 2007, another operation, the third so far, raised the financed cars up to thirty. It is already possible to see in the city that a fraction of the Taxis fleet is new and distinguished. The success of operation has been increasing financing studies over the city's public transport fleet and with the Government partnership.

Analysing this initiative, there are positive results for the partners as well as for the target groups affected by them, just as claimed by Porter and Kramer (2006) and Burke and Logsdom (1996). For the Bank, a financial operation has been established which, for the time being, has turned out profitable. After the first year of contract there was no operation with its credit in delay which points to a great chance of no money loss. The Bank has its advertising in the cars, associating its brand to an initiative of social character, assuring a good reputation near the public. Taxi drivers who had access to the second and third phases of the leasing opened new bank accounts.

For the Taxi drivers this has been a positive partnership. They have had more businesses, transporting more passengers and their cars have the preference of clients. They are semi-new, in good conditions, from a well-known brand (Toyota) and comfortable. This fact is confirmed by Taxi drivers and clients.

For the Taxi Drivers Association this partnership turned out to be very profitable. Moreover besides accomplishing its task of serving the Taxi drivers, it got strength through the raising of its associates number and by their contributions assiduity, which was a selection criteria required to join the operation. Nowadays, the Association is considering the process of enlarging its associate base. 
As far as the Taxi users are concerned, tourists and Maputo inhabitants, the profit is obvious: transport with greater comfort, security and wellbeing.

In relation to the authorities, like the Ministry of Tourism and the Town Hall, the programme "More Taxi For Me" is contributing for the development of the Taxis look, as well as for the accomplishment of the legal obligation of having a motor third party insurance.

\section{5- Final considerations}

Can "More Taxi For Me" be considered a programme that integrates the economic, social and environmental objectives of a company? Does its conception find theoretical support in the BE model presented in this paper?

From the sustainability viewpoint, it is evident that the Program of Taxi Leasing integrates economic and social dimensions. The criterions growth of the credit granting, mainly by the offer of a financing with no down-payment, was a bet based on social values as well as on economic values. The success of the initiative seems to demonstrate that business economic and social purpose are not incompatible. According to Porter and Kramer (2006), efforts to find shared value in operating practices and in the social dimensions of competitive context have the potential not only to foster economic and social development but to change the way companies and society think about each other. "Each company can identify the particular set of societal problems that it is best equipped to help resolve and from which it can gain the greatest competitive benefit” (Porter \& Kramer, 2006, p. 14) .

However, what about the environmental purpose? Considering that the use of more recent vehicles decreases the carbon emissions into the atmosphere, we may say that this purpose is also indirectly reached. The purchase of brand-new cars, though it would raise the financing amount, would be even more accurate from the environmental point of view. Just because they are more recent cars its emission of pollutant is less significant. Though it has an environmental value, which can improve, this value has been absent from the company's speech.

This is an initiative of integrated sustainability, since the economic, social and environmental dimensions (the last one in a lesser degree) are inherent to Taxi Leasing Program. The graphic representation of the case study is shown in Figure 3. Notice that the circle assigned to environmental dimension is smaller than the other though integrated with the others.

Figure 3: Authors' graphic representation of the analysis of Integrated Sustainability (IS) from the Programme More Taxi For Me

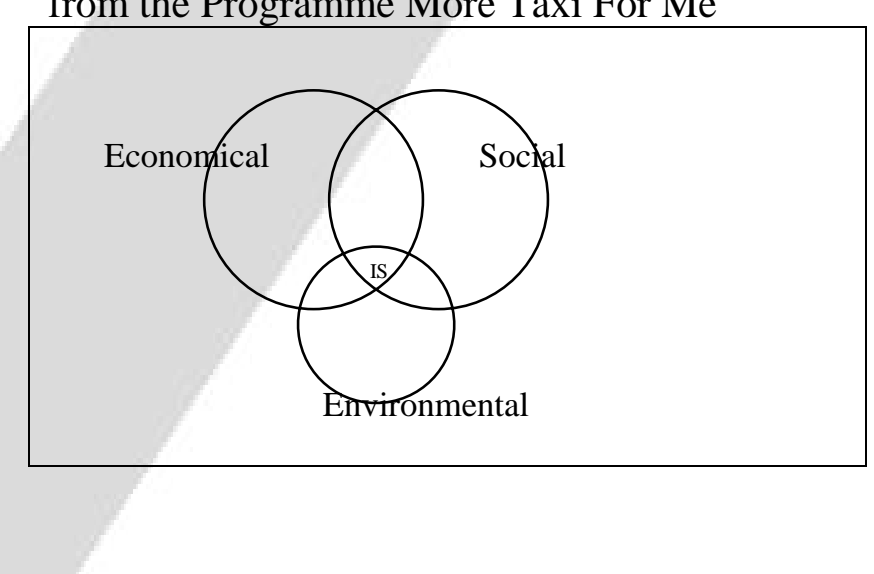


From a BE perspective, we can realize that the company cared for the integration of its engagement on the social development of its country (ethics of conviction), with the ethics of responsibility, through a partnership with an external stakeholder (ATAXIMA) which became an internal stakeholder (a client). The initiative involved other stakeholders, such as the Ministry of Tourism and the Town Hall. It is worthwhile to remember that the initiative also fulfilled the legal obligation to hire the civil insurance responsibility facing third parties. The community, that is, the Taxi users, can also be considered as stakeholders impacted with the partnership between the Bank and ATAXIMA.

The financial aspects and selection of beneficiaries obeyed simultaneously to values that may be considered social and economic. From the viewpoint of the integrated sustainability, those values merge with each others. In accordance with the BE model, the social values may be classified as a value of the company, signatory of Global Compact, and therefore formally engaged with the defence of Human Rights. Hence, it sets in the dimension of the ethics of conviction or affirmative ethics of the humanity's principle. The ethics of virtues is there as ethical values (social development and improvement of the population's way of living) materialized into a sustainable financial and socially relevant product for the community. The graphic representation of the BE model in the case study can be seen in Figure 4:

Figure 4: The appliance of the BE Model in the Program 'More Taxi For Me'

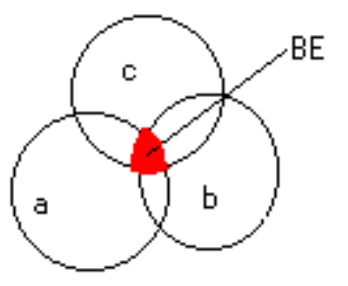

(a) Ethics of Conviction

(b) Ethics of Responsibility

(c) Ethics of Virtues

Source: created by the authors

Despite the high value of the initiative, an unquestionable example of integrated sustainability, a feature deserves to be taken into consideration. For the Bank, the advertising in the cars was justified as an reduction of the operation risk. In this way, under the business perspective, it was being paid by the Bank, and may wonder if the social dimension was being paid by the advertising. As it was not the goal of this research, it was not possible to calculate the cost of publicity and its relation with the Taxi Leasing return rate as well as to compare it to the return rate of a common Leasing operation. For future researches, it is recommended to look for these data, as a way to find out if, in fact, the increase of the business risk is paid by any counter-part, or if it is assumed as a social investment of the company. As the operation of the program does not register delays in payment, could the advertising be considered as a "bonus", free of charge? That question deserves a further research. 


\section{References}

Almeida, Fernando. (2002). O Bom Negócio da Sustentabilidade. Rio de Janeiro: Nova Fronteira, 2002.

Andersen, Arthur. (1992). Business Ethics Program. Ethics Foundation Presentation. Arthur Andersen y Co., SC.

Arruda, M.C.C., Whitaker, Maria. \& Ramos, José. (2001). Fundamentos de ética empresarial e econômica. São Paulo: Atlas.

Atkinson, G. (2000). Measuring corporate sustainability. Journal of Environmental Planning and Management, 43 (2), 235-252.

Benson, G. C. Codes of ethics. (1989). Journal of Business Ethics, 8/5, p. 305-319.

Brooks, L. J. (1989a). Corporate Codes of Ethics. Journal of Business Ethics. 8/2-3, p. 117129.

Brooks, L. J. (1989b). Corporate Ethical Performance, Trends, Forecasts and Outlooks. Journal of Business Ethics. 8/1, p. 31-38.

Burke, L. \&Logsdon, J. M. 1996. How corporate social responsibility pays off. Long Range Planning, 29: 495-502.

Carrol, A. B. (1989). Ethics and stakeholder management. Business and society. Cincinnati: South-Western Publishing.

Clarkson, Max B.E. (1995). A stakeholder framework for analyzing and evaluating corporate social performance. Academy of Management Review, Mississippi State v.20, p.92-117, Jan.

Clarkson, Max B.E. (1994). The Toronto Conference: reflections on stakeholders theory. Business and Society, April.

Coral, Rossetto \& Selig. (2003). Sustentabilidade corporativa e os modelos de planejamento estratégico: uma equação não resolvida. In: In: Encontro Nacional da Associação Nacional dos Programas de Pós-graduação em Administração - ENANPAD 2003, Anais... Atibaia.

Cressey, D. R.; Moore, C. A. (1983). Managerial Values and Corporate Codes of Ethics. California Management Review, 25/4, p. 53-77.

Dal Mas, Patrus-Pena \& Teixeira. (2009). Uma proposta de investigacao de ética no marketing: análise dos valores do código de ética da AMBEV e dos valores presentes em propagandas da cerveja Skol. In: XXXIII Encontro Nacional da ANPAD, 2009, São Paulo. Anais... Curitiba: Anpad.

Dal Mas \& Patrus-Pena (2008) Análise dos valores afirmados da AMBEV e dos valores nas Propagandas da Skol e da Antarctica: Se o cara que inventou a BOA (Bebedores Oficiais de Antarctica) ler esse artigo... In: Encontro de Marketing da ANPAD, 2008, Curitiba. Anais do EMA - Anpad, Curitiba.

Daly, H.E. \& Cobb, J.C. (1994). For the common bood, 2nd Ed., Boston; Beacon.

Elkington, John. (2001) Canibais com garfo e faca. São Paulo: Makron Books.

Francés, P., Borrego, A. \& Velayos, C. (2003). Códigos Éticos en los negocios: creación y aplicación en empresas e instituciones. Madrid: Ediciones Pirámide.

Freeman, R. E. (1984). Strategic management: a stakeholder approach. Boston: Pitman.

Freeman, R. E. (1994). The politics of stakeholder theory: some future directions. Business Ethics Quarterly, 4, 409-422.

Gladwin, T.N., Kennely, J. and Krause, T.; (1995). Shifting paradigms for sustainable development: Implications for management theory and research. The Academy of Management Review, Mississippi State, October.

Grayson, D. \& Hodges, A. (2002). Compromisso Social e Gestão Empresarial. São Paulo: Publifolha.

Hawken, P. (1993). A declaration of sustainability. Utne Reader, September/October. Hoffman, Andrew J. (1995). Integrating environmental and Social Issues into Corporate Practice. Environment. Washington, v.42, n.5, p. 22-32, june 2000. 
Jennings, P.D. \& Zandbergen, P.A. (1995). Ecologically Sustainable Organizations: an Institutional Approach, Academy of Management Review, v.20, n.4, p. 1015-1052.

Jonas, H. (1995). El principio de responsabilidad: ensayo de una ética para la civilización tecnológica. Barcelona: Editorial Herder.

Kant, I. (2002). Crítica da razão prática. São Paulo: Martins Fontes. (KpV)

Lozano, J. (1999). Ética y empresa. Madrid: Editorial Trotta.

Macintyre, A. (1998). Historia de la ética. 6.ed. Barcelona: Paidos. 259p.

Nosso futuro comum (1991). Comissão Mundial sobre Meio Ambiente e Desenvolvimento. Ed. Fundação Getúlio Vargas, $2^{\mathrm{a}}$ edição

Patrus-Pena, R. (2002). De la necessidad y de la possibilidad de la intregración entre la ética y la organización. In: V Congresso Latino Americano de Ética Negócios y Economia. 2002. Anais... Ciudad de México.

Patrus-Pena, R. (2003). Responsabilidade Social da Empresa e Business Ethics: Uma Relação Necessária? In: Encontro Nacional da Associação Nacional dos Programas de Pós-graduação em Administração - ENANPAD 2003, Anais... Atibaia.

Patrus-Pena, R. (2004). La empresa ética: ¿un nuevo paradigma? condiciones, desafíos y riesgos del desarrollo de la Business Ethics. 255f. Tese (Doutorado em Filosofia). Universidad Complutense de Madrid, Madrid.

Patrus-Pena, R., Carvalho Neto, A.; Teodosio, A.; Coelho, H. M. Q.; Fernandes, T. \& Dias, A. (2004). Discurso e prática da responsabilidade social: um estudo sobre a gestão do público interno em empresas signatárias do Global Compact. Belo Horizonte: Editora da PUC Minas, 2004. Relatório de Pesquisa.

Patrus-Pena, R., Queiroz, H., Teodosio, A.; Dias, A. and Fernandes, T. (2007). Responsabilidade social e estratégia: um estudo sobre a gestão do público interno em duas empresas signatárias do Global Compact. Revista Organização e Sociedade, Salvador, v.14, n. 40, jan-mar.

Pires, A.M.F. (2003). Análise do Serviço de Atendimento ao Freqüentador de uma Organização Varejista à Luz do Marco Ético Referencial de Ética nos Negócios Proposto por Lozano. 113f. Dissertação (Mestrado em Administração) - Pontifícia Universidade Católica de Minas Gerais, Belo Horizonte.

Porter, Michael. \& Kramer, Mark R. (2006). Strategy and society: The link between competitive advantage and corporate social responsibility. Harvard Business Review, 12: 7892.

Rainborn, C. A. \& Paine, D. (1990). Corporate codes of conduct: a collective conscience and continuum. Journal of Business Ethics, 9/11, p. 879-889.

Schein, E. (1968). A psicologia na organização. Lisboa: Liv. Clássica. 258p.

Shrivastava, P. Ecocentric management for a risk society. (1995b). Academy of Management Review, 20(1): 118-137.

Shrivastava, P. (1995a). Industrial/Environment Crises and Social Responsibility. Journal of Socio-Economics, v.24, n1.

Solomon, R.C. (1993). Ethics and excellence: cooperation and integrity in business. Oxford: Oxford University Press.

Stevens, B. (1994). An analysis of corporate ethical code studies: where do we go from here. Journal of Business Ethics, 13, p. 63-69.

Vaz, H. C. L. (1988). Escritos de Filosofia II: ética e cultura. São Paulo: Loyola.

Weber, Max. (1959). Le savant et le politique. Paris: Union Générale d’Éditions. p. 165-185. White, B. J. \& Montgomery, B. R. (1980). Corporate codes of conduct. California Management Review, 23/2, p. 80-87. 